\title{
PROSPECTS IN SUSTAINABLE CONTROL OF OIL PALM PESTS AND DISEASES THROUGH THE ENHANCEMENT OF ECOSYSTEM SERVICES - THE WAY FORWARD
}

\author{
NORMAN KAMARUDIN*; IDRIS ABU SEMAN and MOHD MAZMIRA MOHD MASRI*
}

\begin{abstract}
The oil palm environment in Malaysia is rich in many ecosystem services which can be beneficial to control pests and diseases. Some examples are the soil microbes which consist of entomopathogenic fungi and bacteria which can be exploited for insect control, especially bagworms, rhinoceros beetle and termites. The bagworms (Lepidoptera: Psychidae) are currently severely infesting oil palm plantations in Malaysia. The Integrated Pest Management (IPM) of bagworms includes aerial spraying of Bacillus thuringiensis (Bt), cultivation of beneficial plants and fixing of natural pheromone traps. The rhinoceros beetle (Coleoptera: Scarabaeidae), can be managed with the soil fungus Metarhizium and the Oryctes nudivirus (OrNV). The subterranean termite (Isoptera: Rhinotermitidae) can be controlled with two entomopathogenic fungi, Beauveria bassiana and Metarhizium anisopliae which perform similarly as an insecticide. The soil microflora, rich in soil antagonists, can be useful for the control of Ganoderma disease. The Integrated Ganoderma Management (IGM) approach is advocated, which aimed at minimising disease incidence in replanting and prolonging the productive life of the infected palm. Birds are also examples of ecosystem services which can be further exploited for the control of rodents and also insect pests. There are several endemic nocturnal and diurnal bird species inhabiting the oil palm plantation which have the potential to control pests, especially rats and bagworms. This article deliberates on some of the endemic ecosystem services in Malaysia which have been exploited towards the management of major pests and diseases in oil palm. The enhancement of existing and introduced ecosystem services would ensure better management of pests and diseases for the sustainable cultivation of oil palm.
\end{abstract}

Keywords: bagworm, rhinoceros beetle, termite, IPM, Ganoderma, IGM, biological control, insectivorous birds, barn owl, ecosystem services.

Date received: 12 April 2019; Sent for revision: 15 April 2019; Received in final form: 14 April 2019; Accepted: 23 July 2019.

\section{INTRODUCTION}

The oil palm industry in Malaysia constitutes the key pillar of the national economy. Oil palm is planted in more than 5.85 million hectares in 2018 and utilises the largest agricultural land area of more than $60 \%$. In 2017, palm oil and palm kernel oil production recorded close to one-third (75.17 million tonnes) of

\footnotetext{
Malaysian Palm Oil Board, 6 Persiaran Institusi, Bandar Baru Bangi,

43000 Kajang, Selangor, Malaysia.

E-mail: norman@mpob.gov.my
}

world total oils and fats production from a planted area of 19.04 million hectares, mainly from Indonesia and Malaysia. Malaysian palm oil alone fetched RM 46.12 billion export revenue from its Indian and European Union markets (Kushairi et al., 2018). As a commodity, palm oil has not only emerged as an important food source, but has proven to be effectively utilised for food, fuels and chemicals, in developing a sustainable and balanced economy.

The oil palm, however, remains prone to threats by a variety of pests such as insects, vertebrates and diseases. Some of the key insect pests and diseases for oil palm in Malaysia which will be deliberated in this 
article include bagworms (Lepidoptera: Psychidae), rhinoceros beetle (Coleoptera: Scarabaeidae), termite (Isoptera: Rhinotermitidae) and the basal stem rot (BSR) disease caused by Ganoderma. The ecosystem services offered by nocturnal birds (barn owls) and some diurnal birds are also mentioned in relation to the control of rodents and insects.

\section{SUSTAINABILITY ISSUES IN PEST AND DISEASE CONTROL}

\section{Compliance to MSPO and RSPO}

Towards end of 2019, Malaysia is targeting full certification of oil palm plantation with the Malaysian Sustainable Palm Oil (MSPO). In 2018, Malaysia produced 2.99 million tonnes of Rountable Sustainable Palm Oil (RSPO) certified palm oil which contributed to $29.66 \%$ of the world's sustainable certified oils (RSPO, 2019).

One of the principals and criteria of ensuring the certification, the plantation should adopt good agricultural practices (GAP), as stipulated in Principal 4: Good agricultural practice minimising harmful environmental impacts of farming operations, reducing the use of chemical inputs. The oil palm plantation industry should be managed with optimum quantity of fertilisers and chemical pesticides used only as and when necessary. Therefore, implementation of GAP plays an important prerequisite for oil palm plantations to be certified sustainable. To reduce or supplement fertiliser application, nutrient recycling is much advocated, by returning mill residues like empty fruit bunches (EFB) to the field as mulch and leaving the pruned fronds spread in piles along the interrows. Likewise, Integrated Pest Management (IPM) results in reduced chemical pesticides usage, by enhancing the use of biopesticides like Metarhizium fungi and Oryctes nudivirus to control rhinoceros beetle, and Bacillus thuringiensis (Bt) for control of bagworms. The Malaysian Palm Oil Board (MPOB) has also discovered several promising antagonistic (i.e. Pycnoporus sanguineus, Trametes lactinea and Grammothele fuligo) and endophytic microbes (i.e. Hendersonia toruloidea) which can be formulated as supplements to reduce the spread of Ganoderma, hence, also reducing much of the chemical fungicides. The reduced use of chemicals thus makes oil palm cultivation highly sustainable.

\section{Ecosystem Services in the Oil Palm Environment}

Ecosystem services are broadly defined as 'benefits that people obtain from ecosystems' (MA, 2005) and they include services related to provisioning, regulating, supporting and cultural functions, as proposed by Daily (1997). Regulating services relating directly to sustainable agriculture are pollination, pest invasion resistance, natural biological control, and pest and disease regulation. Biodiversity through ecological functions contributes to the regulating services. In pest management, the two important ecological functions are predation and parasitisation, which are linked to biodiversity of predators and parasitoids (Heong, 2008).

The oil palm environment in Malaysia is essentially rich in several ecosystem services which can be beneficial to control pests and diseases. Insects which play important roles as natural enemies to the leaf-eating caterpillars have been identified and documented (Norman et al., 1996; 2017). Soil microbes also consist of many entomopathogenic fungi and bacteria which can be exploited for insect control, especially bagworms, rhinoceros beetle and termites. The soil microflora is also rich in some soil antagonists which can be useful for the control of Ganoderma BSR disease. The microbes, either from the soil ecosystem, or insect cadavers have been isolated and tested against the major insect pests and diseases to justify their ability to control them. Efforts were undertaken by MPOB, together with the industry, to further mass produce these organisms and formulate them into suitable biopesticide products, which can now be used on a commercial basis for the control of the major pests and diseases. Birds are other examples of ecosystem services which can be further exploited for the control of rodents and also insect pests. The barn owl is a classic example that has been used effectively to control rats in many plantations while several endemic bird species inhabiting the oil palm plantation also have the potential to control insect pests, especially leaf-eating caterpillars. This article deliberates on some of the endemic ecosystem services in Malaysia which have potential and can be exploited towards the management of major insect pests and diseases in oil palm.

\section{Biodiversity of Microbes with Potential to Provide Ecosystem Services}

The oil palm ecosystem has a rich biodiversity of soil microbes which have the potential to be utilised to enhance the ecosystem services in plantations. Ramlah et al. (2010) has documented a list of microbes in the oil palm environment which are of importance to agriculture and agroindustries as listed in Table 1. Each genera and species of microbes provides ecosystem services in terms of promoting plant growth, fixing and solubilising soil nutrients, converting green wastes into fertiliser and potentials to be derived as bioinsecticides, biofungicides and bioherbicides. There are also a list of microbes on peat (Tables 2 and 3) which can be similarly exploited to enhance the ecosystem services in peat. 
TABLE 1. LIST OF MICROBES OF IMPORTANCE TO AGRICULTURE AND AGROINDUSTRIES

\begin{tabular}{|c|c|}
\hline Type and functions & Genera and species of microbes \\
\hline Plant growth promoters & $\begin{array}{l}\text { Pseudomonas, Azospirillum, Bukholderia, Bacillus, Enterobacter, } \\
\text { Rhizobium, Erwinia, Alcaligenes, Arthrobacter, Acinetobacter, } \\
\text { Flavobacterium, Trichoderma, Serratia and Klebsiella. }\end{array}$ \\
\hline Nitrogen-fixers & $\begin{array}{l}\text { Rhizobium, Actinobacterium, Brevibacillus, Azospirillum, Azotobacter } \\
\text { (such as A. paspalii, A. chroococcum, A. vinelandii, A. agilis), } \\
\text { Bradyrhizobium, Erwinia and Bacillus (e.g. B. sphaericus). }\end{array}$ \\
\hline Phosphate-solubilisers & $\begin{array}{l}\text { Pseudomonas putida, Enterobacter agglomerans, Chromobacterium lividum, } \\
\text { Klebsiella aerogenes, Enterobacter alvei and Staphylococcus spp. }\end{array}$ \\
\hline Potassium-solubilisers & $\begin{array}{l}\text { Bacterium, Bordetella, Delftia, Dyella, Rhizobium, Sinomonas, } \\
\text { Staphylococcus and Xanthomonas. }\end{array}$ \\
\hline Converters of green wastes to organic fertiliser & Bacillus, Actinomycetes and Trichoderma. \\
\hline Bioinsecticides & $\begin{array}{l}\text { Bacillus thuringiensis, B. israelensis, B. sphaericus, Metarhizium } \\
\text { nisopliae, Beauveria bassiana, Paecilomyces spp., etc. }\end{array}$ \\
\hline Biofungicides & $\begin{array}{l}\text { Burkholderia spp., Trichoderma spp., Stenotrophomonas maltophilia, } \\
\text { Agrobacterium agropyri, Bacillus gladioli, Pseudomonas aeroginosa, } \\
\text { Microbacterium testaneum, B. multivorans, etc. }\end{array}$ \\
\hline Bioherbicides & Exserohilum longirostratum. \\
\hline Biotechnology and food industry & Agrobacterium spp., Lactobacillus plantarum. \\
\hline
\end{tabular}

Source: Ramlah et al. (2010).

\section{BIOLOGICAL CONTROL OF MAJOR INSECT PESTS}

\section{Bagworm}

Bagworms are important leaf-eating pests of oil palm in Malaysia. Bagworm infestations and outbreaks have occurred in Malaysia for over five decades (Cheong and Tey, 2012). This remains to be a problem, despite the fact that effective control measures are available. Bagworm infestations can cause about 33\%-40\% yield losses (Basri, 1993). In 2013, bagworm infestation was an important issue that affected the yield of oil palm due to procrastinated control, especially among smallholders (Tey and Cheong, 2013). According to a previous study in 1988, Metisa plana is ranked as the first most economically significant insect pest of oil palm in Malaysia (Basri et al., 1988). A later survey conducted by Norman and Basri (2007) indicated that M. plana was most widely distributed in oil palm plantations in Peninsular Malaysia followed by Pteroma pendula. Based on analysis of historical records of bagworm infestation done by Ho et al. (2011), over 63955 ha of oil palm in 69 estates in Peninsular Malaysia showed M. plana and P. pendula to be the primary pests (Ho et al., 2011).

IPM is the best strategy for controlling bagworm outbreaks in oil palm cultivated areas (Ramlah et al., 2013; Mohd Mazmira et al., 2010; Najib et al., 2013). IPM of bagworms includes aerial spraying of Bt (Ramlah et al., 2013), cultivation of beneficial plants (Basri et al., 2001) and fixing of natural pheromone traps (Norman and Othman, 2006;
Norman et al., 2010). One of the main components of IPM is the application of Bt which is not affecting the non-target organisms including the oil palm pollinating weevil, Elaeidobius kamerunicus (Najib et al., 2012). Bt as an environmental-friendly microbial insecticide is generally not toxic to freshwater fish (Najib et al., 2014), human, domestic animals and vertebrates (Najib et al., 2015). In a laboratory evaluation it was confirmed that both $B$. thuringiensis Berliner subspecies kurstaki and aizawai are potent against the bagworm, M. plana (Tan et al., 2008). The crystalline protein inclusions produced by $B$. thuringiensis during sporulation are responsible for the insecticidal actions (Nester et al., 2002) and the proteins are highly specific against certain insects orders (Hofte and Whitely, 1989). MPOB has developed a local Bt-based biopesticides product known as Ecobac-1 (EC). Ecobac-1 has been used for aerial spraying in several plantations and smallholder areas to control the outbreak of bagworm which has been quite rampant over the last several years, especially in Perak and Johor (Mohamed Mazmira et al., 2010). In a bagworm infested area in Perak, Norhazwani et al. (2017) showed that at least three consecutive aerial spraying of $\mathrm{Bt}$ are required to control the bagworm below the threshold level, with an overall reduction of $90.8 \%$. Constant vigilance is crucial to monitor the bagworm population level to avoid it from recurring. In Johor, Najib et al. (2017) reported of integrating pheromone traps, using receptive female bagworms placed on sticky traps together with aerial spraying of Bt at several smallholdings. The installation of pheromone traps was carried out at four different 
locations for two consecutive generations of the bagworm, M. plana. Using pheromone traps alone, the successive bagworm population was reduced between $77 \%-89 \%$, while with the addition of $\mathrm{Bt}$ aerial spraying, it was reduced further between $85 \%-94 \%$. This indicates that, at the interim when the bagworm population was not suitable to be sprayed with $\mathrm{Bt}$, pheromone traps can be used to trap the male adults of the bagworms, to reduce the subsequent bagworm population, for better control with Bt.

An important component of the IPM of bagworm is the establishment of beneficial plants. This is a very important but often neglected component whereby the ecosystem services (i.e. insect natural enemies, the parasitoids and predators) cannot establish and survive without the beneficial plants. The oil palm environment therefore can be made more conducive for the population of the pests' natural enemies. The concept of establishing nectar producing, beneficial plants is to prolong the life span of the insect natural enemies and sustaining them in the field to reduce the leaf eating pest population. The interaction of natural enemies with the bagworm was also monitored (Norman and Basri, 2010; Norman and Othman, 2016) and the evaluation of beneficial plants with the natural enemies in the field (Nor Sarashimatun et al., 2011; Yusdayati et al., 2014), which also confirmed previous works conducted by Basri et al. (1999) and Ho et al. (2003). These studies showed that natural enemies play a complementary role towards an ecological balance in maintaining low populations of bagworms below its threshold levels.

There are four species of nectar producing plants which are beneficial to the natural enemies of bagworms, i.e. Cassia cobanensis, Antigonon leptopus, Euphorbia heterophylla and Turnera subulata (Basri et al., 2001; Ho et al., 2003). Planters must therefore seriously consider planting these beneficial plants like C. cobanensis, which provide honey from the leaf nodes as well as from the flowers. Norman and Othman (2016) reported on the important contribution of $C$. cobanensis plants towards enriching the diversity of the parasitoids, which are normally not found within the oil palm planting block, due to much less intense sunlight. Among the dominant parasitoids observed on C. cobanensis plants are chalcids (Brachymeria lugubris and Brachymeria carinata) and braconids (Dolichogenidea metesae and Apanteles aluella), besides the reduuvid predator, Cosmolestes picticeps. These are the agents of the ecosystem services that play a major role in regulating bagworm numbers below the threshold levels. In one plantation block, it was observed that the bagworm, $P$. pendula population was down at negligible levels for two years, together with the establishment of beneficial plants and ferns in the vicinity (Norman and Basri, 2010). Activities of insect predators were seen to be more prominent on ferns while parasitoids preferred to dwell on plants with nectar sources $(C$. cobanensis and Asystasia gangetica). Lesser known predators like the chequered beetle (Callimerus arcufer) (Coleoptera: Cleridae) had shown potential to control the bagworm pupal stages (Cheong and Tey, 2011). Other predatory species like Platynopus melacanthus and Cantheconidea furcellata (Hemiptera: Pentatomidae) and assassin bugs, Sycanus dichotomus and C. picticeps (Hemiptera: Reduviidae) also possess the predatory ability towards the bagworm (Azlina, 2011; Siti Nurulhidayah et al., 2011). The most potential predators for M. plana are C. furcellata, P. melacanthus and S. dichotomus (Azlina, 2011; Jamian et al., 2017). C. picticeps, however, was shown to be a less specific predator and often exhibited cannibalism to its own population which may impede the role as an efficient biocontrol agent for bagworms (Azlina, 2011).

These observations therefore strongly suggest the importance of establishing beneficial plants such as $C$. cobanensis and ferns within the vicinity of oil palm plantations in order to sustain the population of natural enemies for the long-term control of bagworms.

\section{Termites}

In Malaysia, cultivation of oil palm on marginal soil such as peat has increased due to diminishing of suitable soils. In peat areas, the subterranean termite, Coptotermes curvignathus (Isoptera: Rhinotermitidae) can be found on oil palm as early as 12 months after planting and could kill palm up to $5.3 \%$. Area estimation by satellite mapping was conducted in 2009, which showed from a total oil palm planted area of 5.0 million hectares, about $27.4 \%$ or 0.67 million hectares are oil palm planted on peat soil (Wahid et al., 2010). During land clearing, at the initial stage of land preparation, the timber residues created a conducive habitat for termites which later contributed to high occurrence of termites population (Bunting et al., 1927; Rasmussen et al., 1982). Therefore, infestation of termites is common in oil palm plantations developed on peat soils, especially in Sarawak and Sumatra (Lim and Silek, 2001; Sudharto et al., 1991).

Exploring the use of entomopathogenic fungi in controlling the infestation of the termites is not new. Evaluation of entomopathogenic microbes to control termites has also been carried out by various workers. Myles (2002) listed entomopathogenic microbes which included two viruses, five bacteria, 17 fungi, five nematodes and four mites that are potential for termites control. More research attention has been focused on pathogenic fungi as it was easy and cheaper to mass produce, safe to non-target organisms, stable formulation and longer life span in the field (Lenz, 2005). Generally, five 
species of entomopathogenic fungi were reported as potential pathogens to control termites (Andrew and Cheok, 2001). However, several studies focus on only three species, the Beauveria bassiana, Metarhizium anisopliae and Paecilomyces fumosoroseus (Wang and Powell, 2003). Among them, intensive research was then carried out on $M$. anisopliae to control termite species $C$. formosanus especially in Australia (Milner et al., 1998; Milner, 2003). In Malaysia, the application of $M$. anisopliae against $C$. curvignathus at 108 spores $\mathrm{ml}^{-1}$ killed $100 \%$ termites at three days after treatment (Pik-Kheng et al., 2009). Pong et al. (2017) has also isolated many M. anisopliae and Isaria amoenerosea from mineral and peat soils and tested against the subterranean termites, $C$. curvignathus. There are also many types of bacteria (Table 2) and fungi (Table 3) isolated in peat which can be screened as biopesticides for controlling termites. The isolates of M. anisopliae were confirmed more pathogenic on termites compared to the isolates of I. amoenerosea, causing between $71 \%-84 \%$ infections at 15 days after treatment (DAT). More field studies are required to prove the effectiveness in field population of termites.

\section{Rhinoceros Beetle}

The rhinoceros beetle, Oryctes rhinoceros, is one of the major insect pests of oil palm in Malaysia,

TABLE 2. TYPES OF BACTERIA (Prokaryote) FOUND IN A DEEP PEAT AREA IN SARAWAK

\begin{tabular}{ll}
\hline Types of bacteria & Spesies \\
\hline Acidobacteria & Acidobacteriaceae bacterium \\
& Acidobacteriales bacterium \\
& Candidatus koribacter \\
Actinobacterium & Mycobacterium \\
& Streptomyces \\
& Cryobacterium \\
Alpha proteobacterium & Bradyrhizobium sp. \\
& Rhizobiales bacterium \\
& Rhodoplanes sp. \\
& Hyphomicrobiaceae bacterium \\
& Paracoccus sp. \\
& Xanthobacteraceae bacterium \\
& Acetobacteraceae \\
& Methylocystaceae bacterium \\
& Pseudolabrys sp. \\
& Acidocella sp. \\
& Paenibacillus polymyxa \\
Firmicutes & Paenibacillus sp. \\
& Bacillus sp. \\
& Paenibacillus peoriae \\
& Firmicutes bacterium \\
Bacillus amyloliquefaciens & Paenibacillus jamilae \\
& Bacillus subtilis \\
&
\end{tabular}

Source: Maidin et al. (2018). especially in areas being replanted through zeroburning (Norman and Basri, 1997). Decaying chipped oil palm debris in the replanting areas provides excellent breeding sites for the beetle. Newly emerged adults from these replanting areas can severely damage or even kill young palms and expose them to secondary attack of other insect pests, such as the red palm weevil. Since the introduction of zero-burning techniques for replanting in 1990s, outbreaks of $O$. rhinoceros on oil palm plantations are more frequently reported. If no control measures were undertaken, severely attacked palms can suffer high crop loss of up to 25\% per year (Samsudin et al., 1993). IPM for the control of rhinoceros beetle include the usage of chemical insecticides, planting cover crops, destruction of breeding sites and the use of biocontrol agents such as the entomopathogenic fungus, Metarhizium anisopliae and Oryctes nudivirus (OrNV) (Ramle et al., 2007; Bedford, 2014).

The implementation of IPM for O. rhinoceros includes the direct application of the formulated Metarhizium spp. onto the breeding sites of $O$. rhinoceros and the propagation of OrNV via dissemination of Nudivirus infected beetle to the Oryctes population in the breeding sites within the replanting area. Since the late 1990s, intensive research work has been carried on the use of the entomopathogenic fungus, $M$. anisopliae, for the biocontrol of rhinoceros beetle. The common subspecies are $M$. anisopliae var. anisopliae and M. anisopliae var. major. The former has spores of 5-8 um in length and a wide host range, infecting many species of insects. M. anisopliae var. major has a larger spore of 9-14 um in length with fewer hosts, infecting specifically insects of the family Scarabaeidae, such as Oryctes rhinoceros (Sivapragasam and Tey, 1994). It is therefore M. anisopliae var major which has been

TABLE 3. TYPES OF FUNGI (Eukaryote) COLLECTED AT PEAT AREAS IN SARAWAK

\begin{tabular}{ll}
\hline Classes of eukaryote & Genera \\
\hline Major eukaryota & Fungi \\
& Alveolata spp. \\
& Eukaryota spp. \\
Minor eukaryota & Nucleariidae spp. \\
& Rhizaria spp. \\
& Stramenopiles spp. \\
& Ameoboza spp. \\
& Choaflagelida spp. \\
& Fonticula spp. \\
Rare eukaryota & Metazoa spp. \\
& Micronuclearia spp. \\
& Viridiplantae spp. \\
Centroheliozoa spp. & Trimastix spp. \\
Haptophyceae spp. \\
Soil amoeba
\end{tabular}

Source: Ramlah et al. (2018). 
identified to be formulated as a product to control the beetle at its breeding sites.

\section{Bunch Moth}

The bunch moth, Tirathaba rufivena has long been controlled by using chemical pesticides. In the 90s, the pest was most severe in Teluk Intan, Perak in Malaysia and field trials have showed that $\mathrm{Bt}$ is able to replace the commonly used chemical, endosulfan, which has long been used in the control of bunch moth in the area (Basri et al., 1991). Over the last several years, many plantations in Sarawak are similarly experiencing the bunch moth problem, especially in peat areas (Norman et al., 2018). The complication to the issue is when planters use cypermethrin to control Tirathaba, which in turn also kills the pollinating weevil, causing another industrial problem, which is low fruit set. Realising this, efforts were initiated to use biopesticides to replace cypermethrin. Saharul et al. (2017) tested several biological products and insecticides in controlling the infestation of T. rufivena in Sarawak. It was observed that only the commercial Bt and $M$. anisopliae were able to control the larval population of bunch moth up to between 34-49 DAT. Chlorantraniliprole applications, which are safer to pollinating weevil, gave rapid reduction and maintained low population of bunch moth up to 59 days after the last spraying. In Indonesia, several chemical pesticides were also tested together with $\mathrm{Bt}$, which included fipronil and chlorantranilaprole. Fipronil, however, was shown to reduce the pollinating weevils at one month after application, while Bt did not affect the weevil populations, resulting in $>75 \%$ fruit set. Bt treatments were effective in controlling Tirathaba, did not impact the weevil or overall insect biodiversity and positively increased oil palm fruit set, bunch weight and productivity (Prasetyo et al., 2018). This indicates that biological products can also perform equally as effective as the chemical pesticides and its use in bunch moth control needs to be expanded.

\section{BIRDS FOR RODENT AND INSECT PEST CONTROL}

\section{Barn Owl}

The barn owl has been almost synonymous with the oil palm in Malaysia, ever since it was first recorded in late $60 \mathrm{~s}$ in an oil palm plantation in Johor (Duckett, 1991). Then onwards, the barn owl has established itself as the main biocontrol agent of rats in oil palm with the provision of artificial nesting sites/nest boxes in plantations (Lenton, 1980). In the IPM concept, the barn owl has to be integrated with the use of rodenticides at the early stages of establishment, for it to gain an ecological balance with the rats population. The survivorship of the barn owl is somewhat jeopardised by the use of second generation rodenticides which are very harmful, and causing secondary poisoning to the barn owls (Mendenhall and Pank, 1980; Lee, 1994). It is therefore advisable to use only first generation rodenticides such as warfarin (Duckett, 1984). Among the first generation rodenticides besides warfarin, chlorophacinone showed lesser toxic effects to the barn owl compared to bromadialone (Hasber et al., 2013). Besides using anti-coagulant rodenticides, it was reported that the host-restricted apicomplexan protozoon, Sarcocystis singaporensis can cause mortality between $58 \%$ to $92 \%$ of the common rats in oil palm plantations (Jakel et al., 1999). More recently, S. singaporensis formulated as a biorodenticide, performs much better than warfarin and brodifacoum in controlling rats and also achieved the highest reproductive rates in the baited areas, as reflected by the rate of owl fledging success (Naim et al., 2011). With these results, it is now imperative to use biorodenticides over anticoagulants in IPM programmes using the barn owl.

\section{Insectivorous Birds}

An inventory of the diurnal bird species inhabiting the oil palm plantations has been documented (De Chenon and Susanto, 2006; Asrulsani et al., 2012). Whilst some birds are granivores or fruiteaters, most were identified to be insectivores, with their population often fluctuating in tandem with caterpillar outbreaks (De Chenon and Susanto, 2006). The dominant insectivorous bird species feed on caterpillars, small beetles, grasshoppers and ants. An example of an insectivorous species, Parus major, may feed on many insects (nettle caterpillars) daily from $6.55 \mathrm{am}$ to $18.15 \mathrm{pm}$. The Centropus sp. was observed to feed on nettle caterpillar cocoons on the soil. Pycnonotus sp. and Cosyphus sp. feed on a wider range of insects including small beetles, caterpillars and ants. Halcyon sp. catches larger insects in flight (such as grasshoppers and beetles). On the other hand, Orthotomus sp. was recorded to be feeding only on the pollinating weevil Elaeidobius kamerunicus (De Chenon and Susanto, 2006). In this case, bird species such as these may cause a depletion of the weevil population, which relates to a reduced fruit set. Pycnonotus goavier has also been reported similarly to feed on the weevil (Bettycopa et al., 2015).

Insectivorous birds therefore, have the potential to reduce insect pest populations, especially in highly infested areas. Nor Laily et al. (2017) has demonstrated that there are reduced crown and leaf damage with the increase in species richness of the insectivorous birds. Integrating cattle into oil palm husbandry to control undergrowth is 
expected to also improve biodiversity (including avian diversity) in oil palm plantations (Kamil et al., 2019). It was found that oil palm plantations with cattle integration had higher avian diversity than plantations without. Based on the feeding guild of birds, insectivores made up the majority of farmland birds observed. It is therefore a possibility to introduce cattle integration, especially in bagworm infested areas, as means to increase the population of avian insectivores to provide ecosystem service for bagworm control. However, due to the fact that many of these insectivorous birds need holes for nesting which are rather limited in younger oil palm plantings, it seems worthwhile to establish artificial nesting boxes in order to increase the population of these beneficial birds in plantations (De Chenon and Susanto, 2006). Intercropping and crop integration can also help in establishing some bird species in oil palm plantations (Ashraf et al., 2018; Teuscher et al., 2015).

The birds which are present in oil palm plantation, Acridotheres javanicus, Acridotheres tristis, Copsychus saularis, Halcyon smyrnensis and even Merops philippinus have all been observed to be nesting in holes and cavities in palms. Nesting boxes have therefore been designed and tested for C. saularis, A. javanicus and A. tristis in Indonesia (De Chenon and Susanto, 2006).

\section{BIOLOGICAL CONTROL OF WEEDS}

Weeds in oil palm plantations are normally controlled by chemical herbicides. However, in the oil palm environment, there are also many soil microbes (Ramlah et al., 2010) which can be exploited for control of certain weeds. Eleusine indica (goosegrass) is a tropical and common grass weeds found in oil palm plantations in Malaysia. A total of 190 fungi were isolated from the diseased parts of the weed and tested for their potential as a biocontrol agents (BCA) (Maizatul-Suriza et al., 2017). Four isolates were observed to be pathogenic to the targeted weed in vitro, showing initial evidence as potential BCA to suppress E. indica. One of the four isolates, Phoma herbarum was able to be formulated into powder form, and has been used successfully to control E. indica in the field (Rusli et al., 2015). Mortality of E. indica increased significantly at 14 DAT and thereafter stabilised at $80 \%$ after 28 days. However, the treatment did not control the weed's root system and therefore E. indica regenerated again after 42 DAT. In comparison, regeneration of E. indica was recorded at 21 DAT when conventional herbicides mixtures were used (Rusli et al., 2014). There are also many other soil microbes which are potential for weed control and need to be explored.

\section{BIOLOGICAL CONTROL OF OIL PALM DISEASE - Ganoderma}

\section{Integrated Ganoderma Management (IGM)}

MPOB has introduced the Integrated Ganoderma Management (IGM) as an initiative towards the management and control of this disease, which includes sanitation practice during replanting, application of biological agents, fertiliser with beneficial/trace nutrient elements and chemical control. These control measures are aimed at minimising disease incidence in replanting, prolonging the productive life of the infected palm, and delaying the progress of Ganoderma BSR disease. MPOB has also published the standard operating procedure (SOP) guidelines to control Ganoderma as part of an awareness campaign to manage and mitigate this disease more effectively (Idris et al., 2016). Some BSR disease control methods in existing plantings and management strategies at replanting have been achieved and are being implemented in several oil palm plantations and smallholders in Malaysia (Idris et al., 2011).

\section{Biodegradation of Oil Palm Trunk}

During replanting, especially in BSR-infected blocks, the previous infected oil palm stand should be deboled, with the roots and trunk chipped to small pieces to facilitate decomposition. Naidu et al. (2015) assessed the antagonistic and enzymatic activities of non-pathogenic hymenomycetes naturally occurring on the oil palm trunk, to determine their potential as degradation agents, as well as antagonistic properties against G. boninense. There were three fungi identified with high antagonistic activity against G. boninense: Pycnoporus sanguineus, Trametes lactinea and Grammothele fuligo. In addition, another two fungi, Lentinus tigrinus and Rigidoporus sp. were also able to invade sterilised oil palm blocks previously colonised by G. boninense. Colonisation of oil palm blocks by G. fuligo, $P$. sanguineus, Rigidoporus sp., T. lactinea and L. tigrinus resulted in mass losses of between $19 \%-33 \%$ of the oil palm trunk wood block respectively, indicating their potential to be utilised as biodegraders of the oil palm trunk during the replanting process, to avoid Ganoderma reinfection over the next generation of oil palm. There are also many types of bacteria (Table 2) and fungi (Table 3) isolated in peat soil which can be screened as potential lignin degraders and also possibly antagonistic to Ganoderma.

\section{Preventive Treatment Using Biological Agents}

Endophytic fungus, Hendersonia toruloidea. Endophytic microorganisms were chosen for the selection of suitable biocontrol agent of 
BSR disease because they colonise plant tissues internally and their movement is within the plant system, thus providing holistic control and often being unaffected by environment changes. The endophytic fungus, Hendersonia toruloidea has been found strongly antagonistic against Ganoderma in various laboratory and nursery studies. The fungus colonises oil palm roots and does no harm to the host plant. The formulated Hendersonia has been proven to reduce the incidence of Ganoderma disease in oil palm seedlings by up to $69.5 \%$ (Idris, 2012). In a field study, only $4.9 \%$ of palms treated with the Hendersonia formulation showed symptoms of BSR disease, compared to untreated palms, of which $83.3 \%$ had died (Nurrashyeda et al., 2015). Studies had indicated the potential of the Hendersonia formulation to prevent Ganoderma infection in oil palm.

Actinomycetes, Streptomyces nigrogriseolus. The actinomycetes have the ability to effectively suppress many plant diseases. In vitro studies have shown that Streptomyces nigrogriseolus, a soil actinomycete, has the potential as a BCA against Ganoderma disease (Shariffah et al., 2015a, b). Streptomyces was formulated into a dry formulation powder and tested for Ganoderma disease and growth of oil palm seedlings in both nursery and field. Vegetative growth indicated that seedlings treated with Streptomyces gave positive effects on frond height, number of leaves and chlorophyll content without harming the growth of oil palm seedlings. The effectiveness to suppress the development of Ganoderma infection in oil palm was studied in the nursery, with the Streptomyces formulation showing lower number of dead seedlings (43.3\%) compared to untreated seedlings (73.3\%) (Idris et al., 2014). In the field study, only $6.6 \%$ of the palms treated with the Streptomyces formulation showed symptoms of BSR disease and died due to Ganoderma infection compared to the untreated palms of $75.0 \%$ (Shariffah et al., 2015a). More recently, Streptomyces spp. have been isolated from soil samples collected from Crocker Range of Sabah which showed highest percentage inhibition radial growth (PIRG) of $80 \%$ (Lim et al., 2018). The anti-microbial compounds were identified as ribostamycin, benzylmalic acid, landomycin B and salinomycin, which may contribute to the antagonistic effect against $G$. boninense.

Trichoderma. Trichoderma spp. have been the most studied and valued as microbes for biological control on a wide range of plant diseases. Trichoderma harzianum has been recognised as a potential BCA against $G$. boninense in a nursery trial (Sundram et al., 2008). In that study, they reported that the application of two strains of T. harzianum are less effective to control G. boninense, compared to a single strain application. Habu et al. (2018) similarly tested mixtures of Trichoderma spp. (T. asperellum, T. harzianum, and $T$. virens) against $G$. boninense. The mixture of Trichoderma spp. demonstrated a disease reduction of $83.03 \%$ and $89.16 \%$ from the foliar and bole symptoms, respectively. In their trial, there seemed to be no difference in the single or mixture application of several species of Trichoderma. The mechanisms involved in the suppression of $G$. boninense and the anti-fungal compounds released by the endophytic Trichoderma virens 159c was reported by Angel et al. (2018). The presence of phenylethyl alcohol (PEA) in T. virens was prominent as the inhibitory agent to G. boninense. In addition, Habu et al. (2018) have identified that peroxidase (PO), polyphenol oxidase (PPO) and phenolics may play a role in suppressing the manifestation of the Ganoderma disease.

\section{CONCLUSION}

The overall acceptance of palm oil can be further enhanced through the compliance of GAP, being the integral part of both MSPO and RSPO certifications. GAP ensures to reduce chemical inputs, especially pesticides, by improving the environment and enhancing the ecosystem services. Likewise, the integrated pest and disease management concept supports the use of biopesticides and biocontrol agents for the control of insect pests and also disease like Ganoderma. The oil palm ecosystem is known to be rich in soil borne fungi which can be isolated and utilised for both insect and disease control. In addition, there are several species of birds which provide ecosystem services to control rodents and many insect pests. It is hoped that these efforts towards enhancing ecosystem services available within the oil palm environment should gradually reduce the application of chemicals, for a sustainable, long-term control of pests and diseases in oil palm.

\section{REFERENCES}

Andrew, H H W and Cheok, K S (2001). Observations of termite-fungus interactions of potential significance to wood biodeterioration and protection. Timber Technology Bulletin, 24: 1-10.

Angel, L P L; Sundram, S; Bonnie, T Y P; Mohd Termizi, Y and Intan Safinar, I (2018). Profiling of anti fungal activity of Trichoderma virens 159C involved in biocontrol assay of Ganoderma boninense. J. Oil Palm Res. Vol. 30(1): 83-93.

Ashraf, M; Zulkifli, R; Sanusi, R; Tohiran, K A; Terhem, R; Moslim, R and Azhar, B (2018). Alley- 
cropping system can boost arthropod biodiversity and ecosystem functions in oil palm plantations. Agriculture, Ecosystems \& Environment, 260: 19-26.

Asrulsani, J; Badrul, A; Nor Laili, I; Syari, J; Arnina, H; Puan, C L; Hafidzi, M N; Ebil, Y and Mohamed, Z (2012). Avian biodiversity and conservation in Malaysian oil palm production areas. J. Oil Palm Res. Vol. 24 (1): 1277-1286.

Azlina, Z (2011). Killing efficiency of selected insect predator species against bagworm, Metisa plana. Proc. of the PIPOC 2011 International Palm Oil Congress - Palm Oil: Fortifying and Energizing the World: Module 1 - Agriculture, Biotechnology and Sustainability Conference. MPOB, Bangi. p. 46-49.

Basri, M W; Abdul, H H and Zulfikri, M (1988). Bagworm (Lepidoptera: Psychidae) of Oil Palms in Malaysia. PORIM, Bangi.

Basri, M W (1993). Life History, Ecology and Economic Impact of the Bagworm, Metisa plana Walker (Lepidoptera: Phychidae), on the Oil Palm, Elaeis guineensis Jacquin (Palmae). Ph.D thesis. University of Guelph, Ontario, Canada.

Basri, M W; Sharma, M and Norman, K (1991). Field evaluation of insecticides and a cultural practice against the bunch moth Tirathaba rufivena (Lepidoptera: Pyralidae) in a mature oil palm plantation. J. Oil Palm Res. Vol. 3(2): 355-362.

Basri, M W; Simon, S; Ravigadevi, S and Othman, A (1999). Beneficial plants for the natural enemies of the bagworm in oil palm plantations. Proc. of the 1999 PORIM International Palm Oil Congress - Emerging Technologies and Opportunities in the Next Millennium (Ariffin, D; Chan, K W and Sharifah, S R S A eds.). PORIM, Bangi. p. 441-455.

Basri, M W; Norman, K and Othman, A (2001). Field impact of beneficial plants on the parasitism levels of the bagworm, Metisa plana (Lepidoptera: Psychidae). Proc. of the PIPOC 2001 International Palm Oil Congress - Cutting-edge Technologies for Sustained Competitiveness: Module 1 - Agriculture, Biotechnology and Sustainability Conference (unedited). MPOB, Bangi. p. 441-445.

Bedford, G O (2014). Advances in the control of rhinoceros beetle, Oryctes rhinoceros in oil palm. J. Oil Palm Res. Vol. 26(3): 183-194.

Bettycopa, A; Andrew, A T; Khalid, H; Mohd Haniff, H and Norman, K (2015). The diet of yellow vented bulbul (Pycnonotus goiavier) in oil palm agroecosystems. J. Oil Palm Res. Vol. 27(4): 417-424.
Bunting, B; Georgi, C D V and Milsum, J N (1927). The oil palm in Malaya. Malayan Planting Agricultural J., 15: 297-387.

Cheong, Y L and Tey, C C (2011). Checkered beetle, Callimerus arcufer (Coleoptera: Cleridae) and its preparation activity on a bagworms, Metisa plana and Pteroma pendula. Proc. of the PIPOC 2011 International Palm Oil Congress - Palm Oil: Fortifying and Energizing the World: Module 1 - Agriculture, Biotechnology and Sustainability Conference. MPOB, Bangi. p. 50-53.

Cheong, Y L and Tey, C C (2012). Understanding pest biology and behaviour for effective control of oil palm bagworms. The Planter, 88 (1039): 699-715.

Daily, G (1997). Nature's Services: Societal Dependence on Natural Ecosystems. Washington, DC: Island Press. $392 \mathrm{pp}$.

De Chenon, D R and Susanto, A (2006). Ecological observations on diurnal birds in Indonesian oil palm plantations. J. Oil Palm Res. (Special Issue): 122-143.

Duckett, J E (1984). Barn owls (Tyto alba) and the 'second generation' rat-baits utilised in oil palm plantations in Peninsular Malaysia. The Planter, 60:3-11.

Duckett, J E (1991). Management of the barn owl (Tyto alba javanica) as a predator of rats in oil palm (Elaeis guineensis) plantations in Malaysia. Birds of Prey Bulletin No. 4: 11-24.

Habu, M; Khairulmazmi, A and Nusaibah, S A (2018). Assessment on Trichoderma spp. mixture as a potential biocontrol agent of Ganoderma boninense infected oil palm seedlings. J. Oil Palm Res. Vol. 30(3): 403-415.

Hasber, S; Hafidzi, M N; Noor Hisham, H; Dzolkhifli, O; Azhar Kasim and Cik Mohd Rizuan, Z A (2013). Secondary poisoning of captive barn owls, Tyto alba javanica through feeding with rats poisoned with chlorophacinone and bromadiolone. J. Oil Palm Res. Vol. 26(1): 62-67.

Heong, K L (2008). Biodiversity, ecosystem services and pest management. Second International Plantation Industry Conference and Exhibition (IPiCEX 2008). 18-21 November, 2008, Shah Alam. $10 \mathrm{pp}$.

Ho, C T; Yusof, I and Khoo, K C (2011). Infestation by the bagworms Metisa plana and Pteroma pendula for the period 1986-2000 in major oil palm estates managed by Golden Hope Plantation Berhad in Peninsular Malaysia. J. Oil Palm Res. Vol. 23(2): 10401050. 
Ho, C T; Khoo, K C; Yusof, I and Dzolkifli, O (2003). Comparative studies on the use of beneficial plants for natural suppression of bagworm infestation in oil palm. Proc. of the 2003 PIPOC International Palm Oil Congress - Palm Oil, the Power-House for the Global Oil \& Fats Economy: Module 1 - Agriculture, Biotechnology and Sustainability Conference (Unedited). MPOB, Bangi. p. 372-424.

Hofte, H and Whitely, H R (1989). Insecticidal crystal proteins of Bacillus thuringiensis. Microbial Reviews, 53: 242-255.

Idris, A S (2011). Other devastating diseases of oil palm. Further Advances in Oil Palm Research (20002010) (Basri, M W; Choo, Y M and Chan, K W eds.). MPOB, Bangi. p. 522-542.

Idris, A S (2012). Latest research and management of Ganoderma disease in oil palm. Proc. of the Fourth IOPRI-MPOB International Seminar: Existing and Emerging Pests and Diseases of Oil Palm Advances in Research and Management. 13-14 December 2012, Grand Royal Panghegar Hotel, Bandung, Indonesia. p. 1-23.

Idris, AS; Mior, MH AZ; Maizatul, S M and Kushairi, A (2011). Survey on adoption of technology on controlling and managing of Ganoderma disease of oil palm in Malaysia 2009-2010. Proc. of the Third International Seminar Integrated Oil Palm Pests and Management. MPOB, Bangi. p. 116-123.

Idris, A S; Shariffah Muzaimah, S A; Madihah, A Z; Norman, K; Kushairi, A; Choo, Y M; Hamirin, K and Wan Ismail, W H (2014). EmbioTM actinoPLUS for biological control of Ganoderma disease. $M P O B$ Information Series No. 544: 3 pp.

Idris, AS; Nurrashyeda, R; Mohd Hefni, R; Shamala, S and Norman, K (2016). Standard Operating Procedures (SOP) Guidelines for Managing Ganoderma Disease in Oil Palm. MPOB, Bangi. 41 pp.

Jäkel, T; Khoprasert, Y; Endepols, S; ArcherBaumann, C; Suasa-Ard, K; Promkerd, P; Kliemt, D; Boonsong, P and Hongnark, S (1999). Biological control of rodents using Sarcocystis singaporensis. International J. Parasitology Vol. 29 Issue 8: 1321-1330.

Jamian, S; Norhisham, A; Ghazali, A; Zakaria, A and Azhar, B (2017). Impacts of 2 species of predatory Reduviidae on bagworms in oil palm plantations. Insect Science, 24(2): 285-294.

Kamil A Tohiran; Frisco Nobilly; Thomas Maxwell; Chong Leong Puan; Mohamed Zakaria; Raja Zulkifli; Adham Ashton-Butt and Badrul Azhar (2019). Cattle grazing benefits farmland bird community composition in oil palm plantations. Ornithological Science, 18(1): 81-94.

Kushairi, A; Soh Kheang Loh; Azman, I; Elina Hishamuddin; Meilina Ong-Abdullah; Zanal Bidin Mohd Noor Izuddin; Razmah, G; Shamala Sundram and Ghulam Kadir Ahmad Parveez (2018). Oil palm economic performance in Malaysia and R\&D progress in 2017. J. Oil Palm Res. Vol. 30(2): 163-195.

Lee, C H (1994). Secondary toxicity of some rodenticides to barn owls. Proc. of the $4^{\text {th }}$ International Conference of Plant Protection in the Tropics. 28-31 March, Kuala Lumpur, Malaysia. p. 161-163.

Lenton, G M (1980). The Ecology of Barn Owls (Tyto alba) in the Malay Peninsula with Reference to their Use in Rodent Control. Ph.D thesis, Faculty of Science, Universiti of Malaya, Kuala Lumpur.

Lenz, M (2005). Biological control in termite management: The potential of nematodes and fungal pathogens. Proc. of the Fifth International Conference on Urban Pests (Chow-Yang, L and Willian, H R eds.). p. 47-52.

Lim, KH and Silek, B (2001). Termite infestation on oil palms planted on deep peat in Sarawak: Tradewinds experience. Proc of the PIPOC 2001 International Palm Oil Congress - Cutting-edge Technologies for Sustained Competitiveness: Module 1 - Agriculture, Biotechnology and Sustainability Conference (unedited). MPOB, Bangi. p. 355-368.

Lim, P H; Gansau, J A and Chong, K P (2018). Streptomyces spp. A potential biocontrol agent against Ganoderma boninense of basal stem rot. J. Oil Palm Res. Vol. 30(2): 265-275.

MA (Millennium Ecosystem Assessment) (2005). Ecosystems and Human Well-being: Biodiversity Synthesis. Word Resources Institute, Washington, DC, USA. 155 pp.

Maidin, M S T; Sakinah, S; Nur Aziemah, A G; Sharifah Azura, S I; Shamsilawani, A B; Mohamed Mazmira, M M and Ramlah, SAA (2018). Prokaryotic biodiversity in matured oil palm plantation compared to logged over and primary forest in deep peat, Sarawak, Malaysia. J. Oil Palm Res. Vol. 30(3): 451-463.

Maizatul-Suriza, M; Idris, A S; Madihah, A Z and Mohd Hefni, R (2017). Detached leaf assay for in vitro screening of potential biocontrol agents to control goosegrass weed (Eleusine indica). J. Oil Palm Res. Vol. 29(4): 562-569.

Mohamed Mazmira, M M; Siti Ramlah, A A; Mohd Najib, A; Norman, K; Ahmad Kushairi, D and Mohd 
Basri, W (2010). Integrated Pest Management (IPM) of bagworms in Southern Perak via aerial spraying of Bacillus thuringiensis (Bt). Oil Palm Bulletin No. 63: 24-33.

Mendenhall, V M and Pank, L F (1980). Secondary poisoning of owls by anticoagulant rodenticides. Wildlife Society Bulletin, 8: 311-315.

Milner, R J (2003). Application of biological control agents in mound building termites (Isoptera: Termitidae) - Experience with Metarhizium in Australia. Sociobiology, 41: 419-428.

Milner, R J; Staples, J A and Lenz, M (1998). The selection of an isolate of the hyphomycetes fungus, Metarhizium anisopliae for control of termites in Australia. Sociobiology, 41: 429-452.

Mohd Mazmira, M M; Ramlah, A A S; Najib, M A; Norman, K; Kushairi, A D and Basri, M W (2010). Integrated Pest Management (IPM) of bagworms in Southern Perak via aerial spraying of Bacillus thuringiensis (Bt). Oil Palm Bulletin No. 63: 24-33.

Myles, T G (2002). Isolation of Metarhizium anisopliae (Deuteromycotina: Hyphomycetes) from Reticulitermes flavipes (Isoptera: Rhinotermitidae) with convenient methods for its culture and collection of conidia. Sociobiology, 40: 257-262.

Naidu, Y; Idris, A S; Nusaibah, A; Norman, $\mathrm{K}$ and Siddiqui, $\mathrm{Y}$ (2015). In vitro screening of biocontrol and biodegradation potential of selected hymenomycetes against Ganoderma boninense and infected oil palm waste. Forest Pathology, 45: 474-483.

Naim, M; Hafidzi, M N; Azhar, $\mathrm{K}$ and Jalila, A (2011). Comparison of the breeding performance of the barn owl, Tyto alba javanica under chemical and bio-based rodenticide baiting in immature oil palms in Malaysia. Dynamic Biochemistry, Process Biotechnology and Molecular Biology. p. 5-11.

Najib, M A; Ramlah, AAS; Mohd Mazmira, M M and Zaini, M A (2012). Effect of Bt products, Lepcon-1, Bafog-1 (S) and Ecobac-1 (EC), against the oil palm pollinating weevil, Elaeidobius kamerunicus, and beneficial insects associated with Cassia cobanensis. J. Oil Palm Res. Vol. 24(1): 1442-1447.

Najib, M A; Ramlah, A A S; Mohd Mazmira, M M and Basri, M W (2013). Efficacy of Bafog-1 (s), formulated local Bacillus thuringiensis for controlling bagworm, Pteroma pendula (Lepidoptera: Psychidae). J. Oil Palm Res. Vol. 25(2): 228-234.

Najib, M A; Ramlah, A A S; Mohd Mazmira, M M and Noorazah, Z (2014). Lepcon-1, Bafog-1 (S) and
Ecobac-1 (EC), Bacillus thuringiensis based-products are not toxic against the freshwater fish, Tilapia nilotica. J. Oil Palm Res. Vol. 26(4): 317-320.

Najib, M A; Ramlah, A A S; Mohd Mazmira, M M and Zaini, M A (2015). Effect of Bacillus thuringiensis based-products on rats. J. Oil Palm Res. Vol. 27(1): 3038.

Najib, M A; Norman, K; Siti Nurulhidayah, A; Othman, A; Mohamed Mazmira, M M; Ramle, M and Kushairi, A (2017). Efficacy of pheromone trapping and aerial spraying of Bacillus thuringiensis (Bt) for controlling bagworm, Metisa plana Walker (Lepidoptera: Psychidae) in Yong Peng, Johor, Malaysia. J. Oil Palm Res. Vol. 29(1): 55-65.

Norhazwani, K; Siti Ramlah, A A; Mohamed Mazmira, M M; Mohd Najib, A; Che Ahmad Hafiz, C M and Norman, K (2017). Controlling Metisa plana Walker (Lepidoptera: Psychidae) outbreak using Bacillus thuringiensis at an oil palm plantation in Slim River, Perak, Malaysia. J. Oil Palm Res. Vol. 29(1): 47-54.

Nester, E W; Thomashow, L S; Metz, M and Gordom, M (2002). 100 Years of Bacillus thuringiensis: $A$ Critical Scientific Assessment. Ithaca, New York. p. 22.

Nor Laily, I; Norhisham, R; Norman, K; Mohamed, Z; Puan, C L; Siti Nurhidayu and Badrul Azhar (2017). Insectivorous bird richness reduce damages by bagworms in oil palm plantations. Proc. of the PIPOC 2017 International Palm Oil Congress - Treasuring the Past Charting the Future: Module 1 - Agriculture, Biotechnology and Sustainability Conference. MPOB, Bangi. p. 179-184.

Norman, K; Walker, A K; Mohd Basri, W; Lasalle, J and Polaszek, A (1996). Hymenopterous parasitoids of the bagworm, Metisa plana and Mahasena corbetti on oil palm in Peninsular Malaysia. Bulletin of Entomological Research, 86: 423-439.

Norman, H K; Basri, M W and Zulkefli, M (2017). Handbook of Common Parasitoids and Predators Associated with Bagworms and Nettle Caterpillars in Oil Palm Plantations. MPOB, Bangi. 30 pp.

Norman, Kand Othman, A (2006). Potentials of using the pheromone trap for monitoring and controlling the bagworm, Metisa plana Wlk (Lepidoptera: Psychidae) on young oil palm in a smallholder plantation. J. Asia-pacific Entomology, 9: 281-285.

Norman, K and Basri, M W (2010). Interactions of the bagworm, Pteroma pendula (Lepidoptera: Psychidae), and its natural enemies in an oil palm plantation in Perak. J. Oil Palm Res. Vol. 22 (1): 758-764. 
Norman Kamarudin; Siti Nurulhidayah, A and Basri, M W (2010). Pheromone mass trapping bagworm moths Metisa plana (Lepidoptera: Psychidae) for its control in mature oil palms in Perak, Malaysia. J. Asia-Pacific Entomology, 13: 101-106.

Norman, K and Othman, A (2016). Diversity and activity of insect natural enemies of the bagworm (Lepidoptera: Psychidae) within an oil palm plantation in Perak, Malaysia. J. Oil Palm Res. Vol. 28(3): 296-307.

Norman, K and Basri, M W (1997). Status of rhinoceros beetle, Oryctes rhinoceros (Coleoptera: Scarabaeidae) as a pest of young oil palm in Malaysia. The Planter, 73(850): 5-21.

Norman, K and Basri, M W (2007). Status of common insect pest in relation to technology adoption. The Planter, 83: 371-385.

Norman, K; Ramle, M; Saharul Abilah, M and Rosman, S (2018). Fruit set and weevil pollination issues. The Planter, 94 No. 1110.

Nor Sarashimatun, S; The, C L and Tey, C C (2011). Evaluation of beneficial plants as hosts for natural enemies of oil palm bagworms. Proc. of the PIPOC 2011 International Palm Oil Congress: Palm Oil Fortifying and Energizing the World Palm Oil: Module 1 - Agriculture, Biotechnology and Sustainability Conference. MPOB, Bangi. p. 36-40.

Nurrashyeda, R; Idris, A S; Norman, K; Kushairi, A; Wan Azha, W M and Charles, T (2015). GanoEF biofertilizer as preventive treatment of Ganoderma disease in oil palm - Nursery and field evaluation. Paper presented at the PIPOC 2015 International Palm Oil Congress. 6-8 October 2015, Kuala Lumpur, Malaysia. 11 pp.

Pik-Kheng, H; Chong-Fah, B J; Kadir, J and Amartalingam, R (2009). Evaluation of Metarhizium anisopliae (Deuteromycotina: Hyphomycete) isolates and their effects on Subterranean termite Coptotermes curvignathus (Isoptera: Rhinotermitidae). American J. Agricultural and Biological Sciences, 4(4): 287-297.

Pong, K K; Ramle, M; Wahizatul Afzan, A; Norman, $\mathrm{K}$ and Siti Ramlah, A A (2017). Genetic variation of entomopathogenic fungi, Metarhizium anisopliae and Isaria amoenerosea and their pathogenicity against the subterranean termite Coptotermes curvignathus. J. Oil Palm Res. Vol. 29(1): 35-46.

Prasetyo, A E; Lopez, J A; Eldridge, J R; Zommick, D $\mathrm{H}$ and Susanto (2018). A long term study of Bacillus thuringiensis application to control Tirathaba rufivena, along with the impact to Elaeidobius kamerunicus, insect biodiversity and oil palm productivity. J. Oil Palm Res. Vol. 30 (1): 71-82.

Ramlah, S A A; Nor Shalina, A T; Shamsilawani, A B and Basri, M W (2010). Inventory of microbial biodiversity in some oil palm plantations. $M P O B$ Information Series No. 474: 4 pp.

Ramlah, S A A; Najib, M A; Mohd Mazmira, M M; Tajuddin, N A; Keni, M F and Norman, K (2013). Microbial control for pests and diseases and its challenges. Proc. of the PIPOC 2013 International Palm Oil Congress - Green Technologies from the Golden Crop: Module 1 - Agriculture, Biotechnology \& Sustainability Conference. MPOB, Bangi. p. $67-77$.

Ramlah, S A A; Mohd Noor, M I; Sakinah, S; Maidin, M S T and Sharifah Azura, S I (2018). Eukaryotic Biodiversity in mixed peat ecosystems in Sarawak, Malaysia. J. Oil Palm Res. Vol. 30(3): 429- 450.

Ramle, M; Norman, K; Ang, B N; Ramlah Ali, S A and Basri M W (2007). Application of powder formulation of Metarhizium anisopliae to control Oryctes rhinoceros in rotting oil palm residues under leguminous cover crops. J. Oil Palm Res. Vol. 19:318330.

Rasmussen, A N; Kanapathy, K; Santa, M and Gurmit, S (1982). Establishment of oil palm in deep peat from jungle. Oil Palm in Agriculture in Eighties (Pushparajah, E and Chew, P S eds.). Vol. 1. The Incorporated Society of Planters, Kuala Lumpur. p. 641-561.

Roundtable of Sustainable Palm Oil (RSPO). https:/ / rspo.org/ certification/ search-for-certifiedgrowers, accessed on 20 March 2019.

Rusli, M H; Sharifah Muzzaimah, S A; Maizatul Suriza, M and Idris, A S (2015). Powder formulation of Phoma herbarum as biocontrol of goose grass (Eleusine indica). MPOB Information Series No. 694: 2 pp.

Rusli, M H; Idris, A S; Norman, K and Sim, K C (2014). The combination effect of MSMA and Diuron in controlling glyphosate resistant Eleusine indica in oil palm plantation. The Planter, 90(1064): 801-815.

Saharul Abillah, M; Zulkefli, M; Ramle, M; Mohamad Rosman, S; Su, C M; Siaw, T C; Norman, K; Siti Ramlah, A A and Siti Nurulhidayah, A (2017). Biological agents and insecticides to control bunch moth, Tirathaba rufivena in oil palm estates in Sarawak, Malaysia. J. Oil Palm Res. Vol. 29(3): 323-332.

Samsudin Amit; Chew, P S and Mohd, M M (1993). Oryctes rhinoceros: Breeding and damage on oil 
palms in an oil palm to oil palm replanting situation. The Planter, 69 No. 813: 583-591.

Shariffah-Muzaimah, S A, Idris, A S; Madihah, A Z; Kushairi, A; Norman, K; Hamirin, K and Wan Ismail, W H (2015a). Evaluation of EMBIOTM actinoPLUS for biological control of Ganoderma disease in oil palm: Nursery and field results. Paper presented at the PIPOC 2015 International Palm Oil Congress. 6-8 October 2015, Kuala Lumpur, Malaysia. 9 pp.

Shariffah-Muzaimah, S A; Idris, A S; Madihah, A Z; Dzolkhifli, O; Kamaruzzaman, $\mathrm{S}$ and Cheong, P C H (2015b). Isolation of actinomycetes from rhizosphere of oil palm (Elaeis guineensis Jacq.) for antagonism against Ganoderma boninense. J. Oil Palm Res. Vol. 27(1): 19-29.

Siti Nurulhidayah; Norman Kamarudin and Zulkefli Masijan (2011). Mixed preys as food sources for mass rearing the bagworm predator, Sycanus dichotomus. МРОВ Information Series. No. 486: 4 pp.

Sivapragasam, A and Tey, C C (1994). Susceptibility of Oryctes rhinoceros (L.) larvae to three isolates of Metarhizium anisopliae (Metsch.) Sorokin. MAPPS Newsletter, 18 (2): 13-14.

Sudharto, P S; Sipayung, A and Desmier De Chenon, R (1991). Termites - A new problem on oil palm plantations in Indonesia. Proc. of the 1991 PORIM International Conference - Progress, Prospect and Challenges toward the $21^{\text {st }}$ Century. Module 1Agriculture. p. 407-417.

Sundram, S; Faridah, A; Zainal Abidin, M A and Umi Kalsom, Y (2008). Efficacy of single and mixed treatments of Trichoderma harzianum as biocontrol agents of Ganoderma basal stem rot in oil palm. J. Oil Palm Res. Vol. 20: 470-483.

Tan, S Y; Ibrahim, Y and Omar, D (2008). Efficacy of Bacillus thuringiensis Berliner subspecies kurstaki and aizawai against the bagworm, Metisa plana Walker on oil palm. J. Bioscience, 19(1): 103-114.

Teuscher, M; Vorlaufer, M; Wollni, M; Brose, U; Mulyani, Y and Clough, Y (2015). Trade-offs between bird diversity and abundance, yields and revenue in smallholder oil palm plantations in Sumatra, Indonesia. Biological Conservation, 186: 306-318.

Tey, C C and Cheong, Y L (2013). Challenges in Integrated Pest Management (IPM). Proc. of the $10^{\text {th }}$ NATSEM 2013 - Confronting Management Challenges in the Oil Palm Industry. Incorporated Society of Planters, Kuala Lumpur. p. 117-127.

Wahid, O; Nordiana, A Z; Ahmad Tarmizi, M; Mohd Haniff, H and Ahmad Kushairi, D (2010). Mapping of oil palm cultivation on peatland in Malaysia. MPOB Information Series No. 529: 4 pp.

Wang, C and Powell, J E (2003). Isolation and evaluation of Beauveria bassiana for control of Coptotermes formosanus and Reticulitermes flaviceps (Isoptera: Rhinotermitidae). Sociobiology, 41: 369-381.

Yusdayati, R; Che Salmah, M R; Abu Hassan, A and Noor Hisham, H (2014). Diversity and distribution of natural enemies (Predators and Parasitoids) of bagworms (Lepidoptera: Psychidae) on selected host plants in an oil palm plantation. The Planter Vol. 90 No. 1055: 91-101. 